\title{
Ultrastructure of in vitro oocyte maturation in buffalo (Bubalus bubalis)
}

\author{
Rafael Gianella Mondadori ${ }^{1}$, Tiago Rollemberg Santin ${ }^{2}$, Andrei Antonioni Guedes Fidelis ${ }^{3}$, \\ Khesller Patrícia Olázia Name ${ }^{4}$, Juliana Souza da Silva ${ }^{4}$, Rodolfo Rumpf ${ }^{5}$ and Sônia Nair Báo ${ }^{4}$ \\ Molecular Biology Graduation Program, UnB, Brasília-DF, Brazil and Federal University of Pelotas, Morphology Department, \\ Biology Institute, Veterinary Medicine, Pelotas - RS; Department of Cellular Biology, Institute of Biological Science, University \\ of Brasilia, Brasilia-DF; and Empresa Brasileira de Pequisa Agropecuária-EMBRAPA-CENARGEN, Brasília-DF, Brazil
}

Date submitted: 16.09.09. Date accepted: 04.11.09

\section{Summary}

The objective of the present study was to describe ultrastructural changes in the nucleus and cytoplasmic organelles during in vitro maturation (IVM) of buffalo cumulus-oocyte complexes (COCs). The structures were collected by ovum pick-up (OPU). Some COCs, removed from maturation medium at 0, 6, 12, 18 and $24 \mathrm{~h}$, were processed for transmission electron microscopy. The average number of COCs collected by OPU/animal/session was 6.4 , and $44 \%$ of them were viable. Immature oocytes had a peripherally located nucleus, Golgi complex and mitochondrial clusters, as well as a large number of coalescent lipid vacuoles. After $6 \mathrm{~h}$ of IVM, the oocyte nucleus morphology changed from round to a flatter shape, and the granulosa cells (GC) lost most of their contact with zona pellucida (ZP). At $12 \mathrm{~h}$ the first polar body was extruded and the aspect of lipid droplet changed to dark, probably denoting lipid oxidation. Cortical granules were clearly visible at $18 \mathrm{~h}$ of maturation, always located along the oocyte periphery. At $24 \mathrm{~h}$ of IVM the number of cortical granules increased. Ultrastructure studies revealed that: (1) immature oocytes have a high lipid content; (2) the perivitelline space (PS) increases during IVM; (3) Golgi complexes and mitochondrial clusters migrate to oocyte periphery during IVM; (4) $6 \mathrm{~h}$ of IVM are enough to lose contact between GC and ZP; (5) the oocyte lipid droplets' appearance changes between 6 and $12 \mathrm{~h}$ of IVM.

Keywords: Embryo production, Murrah buffalo, Transmission electron microscopy

\section{Introduction}

Superovulatory response and embryo recovery rates in buffalo are lower than in bovines (Baruselli \& Cavalho, 2003). The number of stimulated follicles and embryos collected in buffalo normally corresponds to one-third of that obtained in cattle (Singh et al., 2000). Despite

\footnotetext{
${ }^{1}$ All correspondence to: Rafael Gianella Mondadori. Universidade Federal de Pelotas, Instituto de Biologia, Departamento de Morfologia, Av. Duque de Caxias, 250, Bairro Fragata, Pelotas-RS, 96030-002, Brazil. Tel/Fax: +55 533281 1326. e-mail: rmondadori@hotmail.com; rafael.mondadori@ ufpel.edu.br.

${ }^{2}$ SQN 202, Bloco F, Apto 101, Brasilia - DF, Brazil.

${ }^{3}$ SQS 216, Bloco C, Apto 203, Brasilia - DF, Brazil.

${ }^{4}$ Department of Cellular Biology, Institute of Biological Science, University of Brasilia, Brasilia-DF, Brazil.

${ }^{5}$ Empresa Brasileira de Pequisa Agropecuária-EMBRAPACENARGEN, Brasília-DF, Brazil.
}

efforts to use different hormones/protocols (Misra et al., 1998; Carvalho, 2001; Baruselli et al., 2003), only 50 to $55 \%$ of the animals respond: these buffaloes ovulate two to four structures, producing one or four viable embryos (Manik et al., 2002). Considering this, in vitro embryo production (IVEP) technology represents the best tool to improve maternal contribution to genetic progress in buffalo. Besides the progress obtained in the percentage of in vitro produced transferable embryos (Gasparrini et al., 2006, Manjunatha et al., 2009), the pregnancy rate achieved by transferring these structures remains poor (Gasparrini, 2002; Nandi et al., 2002a).

In vitro embryo production (IVEP) in buffalo is based on the bovine model. Despite some modifications made to improve the process (Gasparrini, 2002; Presicce, 2007), it is generally observed by different research groups that embryo production is only between 15 and 30\% (Presicce, 2007, Liang et al., 
2008, Manjunatha et al., 2008). Ultrastructural studies on the oocyte during in vitro maturation in different mammalian species [mouse (Merchant \& Chang, 1971), human (Zamboni \& Thomson 1972), cattle (Hyttel et al., 1997), camel (Kafi et al., 2005)] have resulted in a better understanding of the biology of the oocyte and, as a consequence, improvements in IVM and IVF. However, systematic studies on ultrastructure of buffalo oocytes during IVM have not been reported. Therefore, the objective of the present study was to describe ultrastructural changes in the nucleus and cytoplasmic organelles of buffalo oocytes during in vitro maturation.

\section{Materials and methods}

\section{Animals}

The experiments were conducted between July and August, winter in the Southern hemisphere, in Planaltina-Federal District-Brazil $\left(15^{\circ} 38^{\prime} \mathrm{S}\right.$ and $47^{\circ} 43^{\prime}$ $\mathrm{W})$. The average maximum temperature during the period was $29.3^{\circ} \mathrm{C}$, while the average minimum temperature was $16.2^{\circ} \mathrm{C}$. During the experimental period there was no rainfall and the animals were fed ad libitum with Panicum spp., mineral supplement and received corn silage. The 10 primiparous Murrah females submitted to ovum pick-up (OPU) were aged between 3 and 4 years, the average body weight was $360 \mathrm{~kg}$ and the corporal score between 2 and 3 (Moreira et al., 2000). Before OPU sessions began, the animals were submitted to a complete gynaecological examination, including ultrasonography of the ovaries.

To eliminate the dominant follicle, selected animals were fitted for 8 days with a progesterone implant $\left(\right.$ CIDR $^{\circledR}$ - Pfizer, São Paulo, Brazil) and estradiol benzoate (Estrogin ${ }^{\circledR}$ - FarmaVet) i.m. on progesterone implant removal. Two days after progesterone implant removal, animals were subjected to three sessions of OPU with an interval of 7 days between sessions. On any given day, OPU from 10 animals was undertaken.

\section{Ovum pick-up (OPU)}

Just before OPU procedure, the animals received $3 \mathrm{ml}$ of lidocaine 2\% (Anesthetic Pearson ${ }^{\circledR}$ - Eurofarma, São Paulo, Brazil) via epidural route, without any further sedation. The ultrasound equipment used was an Aloka SSD-500 with a micro convex $5.0 \mathrm{MHz}$ probe coupled to a vaginal support equipped with aspiration guide (Watanabe Tecnologia Aplicada). All follicles, from 2 to $8 \mathrm{~mm}$, were punctured with an 18-gauge needle connected to a vacuum system (Watanabe Tecnologia Aplicada) adjusted to $-40 \mathrm{mmHg}$. During aspiration procedure, the aspiration line was constantly washed with LAV medium (100 $\mu$ l of heparin (Liquemine ${ }^{\circledR}-$ Roche), $500 \mu \mathrm{l}$ of fetal calf serum (FCS) and q.s.p. $50 \mathrm{ml}$ of PBS). The collected COCs were classified under a stereomicroscope, and only grade I and II (Gupta et al., 2002) structures were used.

\section{Ultrastructural changes during in vitro maturation}

All media and supplements used in the experiment were donated by Nutricell ${ }^{\circledR}$ Nutrientes Celulares Ltda (Campinas).

\section{In vitro maturation}

A total number of 85 COCs were matured in TCM199 with Earle's salts supplemented with $10 \%$ FCS, LH, FSH, L-glutamine, penicillin and streptomycin. Each group of 10 to 15 COCs was matured in $150 \mu \mathrm{l}$ microdrops of medium, covered with mineral oil $\left(\right.$ AMRESCO $\left.^{\circledR}\right)$, previously stabilized in an incubator at $38.5^{\circ} \mathrm{C}$, saturated humidity and $5 \% \mathrm{CO}_{2}$ in air. The IVM procedure was repeated three times.

Each repetition used an average of 28.3 COCs. Five to six structures were removed from maturation drops at $0,6,12,18$ and $24 \mathrm{~h}$ of maturation and processed as described below. Approximately five structures were evaluated by transmission electron microscopy at each time point.

\section{Preparation of COCs for transmission electron microscopy (TEM)}

The structures were fixed in Karnovsky solution ( $2 \%$ glutaraldehyde, $2 \%$ paraformaldehyde, 3\% sucrose, in $0.1 \mathrm{M}$ sodium cacodylate buffer, $\mathrm{pH} 7.2$ ) at $4{ }^{\circ} \mathrm{C}$ for $24 \mathrm{~h}$. Before the post-fixation performed with osmium tetroxide, the COCs were embedded in $4 \%$ agar $\left(\right.$ Difco ${ }^{\circledR}$ ) to facilitate manipulation (Hyttel \& Madsen, 1987). The material was then contrasted in block with uranyl acetate 3\% and the structure was dehydrated with acetone. Dehydrated COCs were included in Spurr (Polysciences) and semi-thin sections $(2 \mu \mathrm{m})$ were performed. To allow detection of the nucleus (equatorial region), the serial sections were dyed with toluidine blue and observed under light microscopy. The ultrathin sections $(90 \mathrm{~nm})$ were made from COCs with intact nucleus and were contrasted with uranyl acetate and lead citrate to be observed with transmission electron microscopy (Jeol 1011) operated at $80 \mathrm{kV}$.

\section{Results}

The average number of COCs collected by OPU/animal/session was 6.4 , and $44 \%$ of them were 


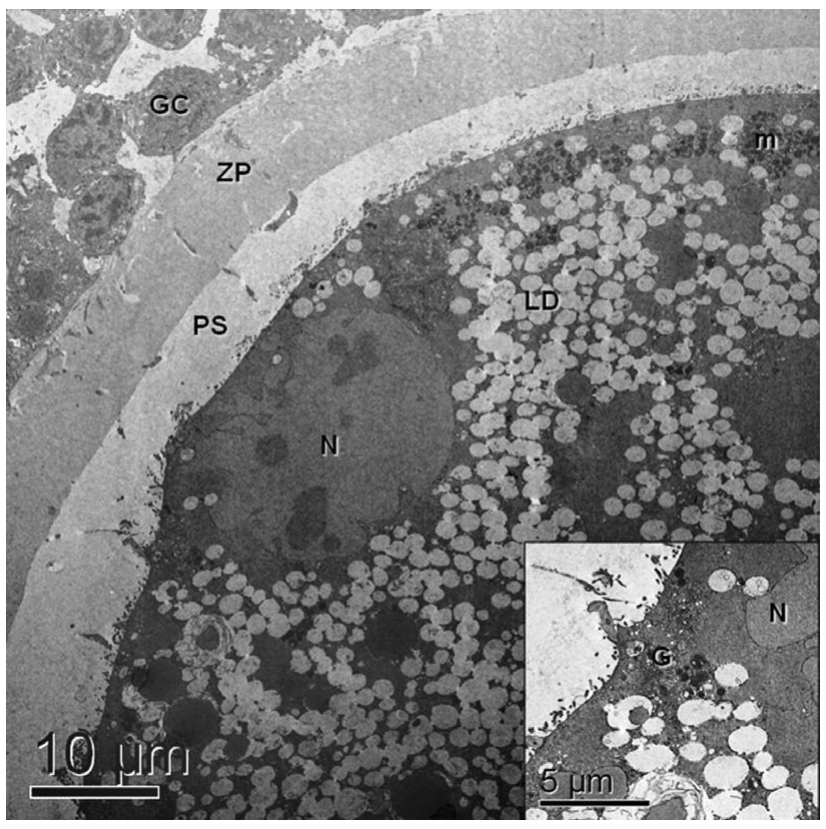

Figure 1 Immature oocyte (TEM). showing lipid droplets (LD), peripherally located mitochondrial clusters $(\mathrm{m})$ and nucleus (N); granulosa cells (GC) intimately related to zona pellucida (ZP), and well developed perivitelline space (PS). Note inset showing a well developed Golgi complex (G).

of grades I and II. During successive OPU sessions the average number of collected COCs/animal decreased, from 8.3 in the first session to 3.9 total structures per animal in the last session. In addition, the percentage of grade I and II (Gupta et al., 2002) structures also decreased from $47 \%$ to $35 \%$. It was also important to note the remarkable individual variation: one animal produced an average of 11 structures, while another just produced three COCs per OPU section. Animal individuality also affected the percentage of viable structures, with some animals producing $100 \%$ usable structures and others just $5.88 \%$.

\section{Ultrastructural changes during in vitro maturation}

Figure 1 shows an immature COC obtained from antral follicle. The oocyte nucleus with loose chromatin is peripherally located. Observing the structural aspects, such as ooplasm and granulosa cell (GC) nuclei, it is possible to infer that the structure is functionally viable. The GC nucleus presented loose chromatin, showing the high activity in protein synthesis of these cells, which will support the oocyte maturation. It is also important to observe the intimate relation between corona radiata cells and zona pellucida (ZP), including the presence of cytoplasmic projections in ZP. The perivitelline space (PS) is well developed and the presence of a large number of bent oocyte microvilli is also noted. Mitochondria, as well as the

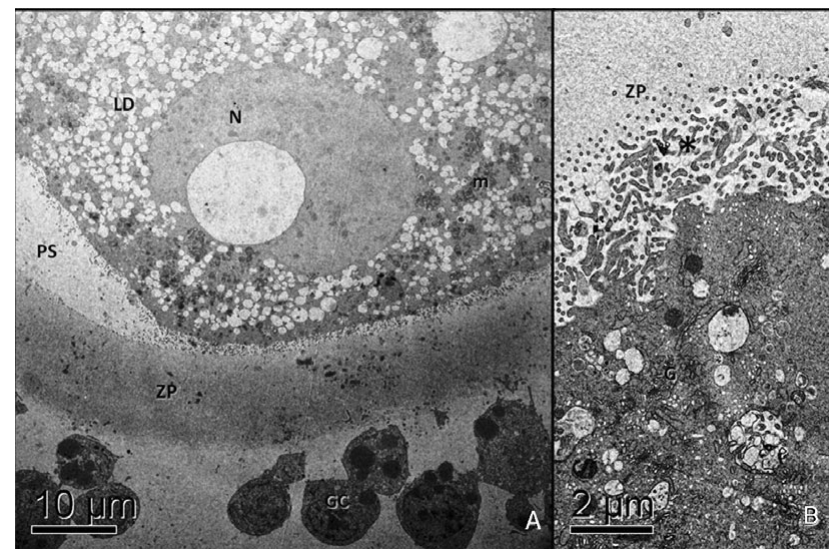

Figure 2 (A) Six-hour matured oocyte (TEM), showing a large number of lipid droplets (LD), peripherally located mitochondrial clusters $(\mathrm{m})$ and nucleus $(\mathrm{N})$; granulosa cells (GC) are coming loose from zona pellucida (ZP) and the perivitelline space (PS) is larger near the nucleus, possibly preparing for polar body extrusion. In (B) it is also possible to note a well developed Golgi complex (G), probably involved in cortical granule production and ooplasm vilosities $(*)$ embedded in ZP.

Golgi complex, are clustered in the oocyte cortical region. Most ooplasm is occupied by a large number of coalescent lipid vacuoles.

After $6 \mathrm{~h}$ of IVM the oocyte nucleus changed its round shape to a more flattened aspect (Fig. 2). Near the nucleus the PS is larger than in the rest of the oocyte, and not filled with ooplasm villi, unlike the rest of the structure. Mitochondria, Golgi complex and lipid vacuoles did not show significant changes during the first $6 \mathrm{~h}$ of maturation. Considerable loosening of GC from $\mathrm{ZP}$ took place during this time.

At $12 \mathrm{~h}$ of IVM (Fig. 3), the first polar body (PB) was extruded into a large PS, showing that the oocyte had reached metaphase II stage. The GC separated completely from ZP. Morphological features of lipid droplets also changed at this time point, which may indicate chemical changes.

Figure 4 shows the peripheral region of an oocyte matured for $18 \mathrm{~h}$. The lipid droplets maintain a dark appearance and the PB is located in a PS filled with ooplasm villi. The most important change observed at this stage is the presence of cortical granules located in the ooplasm cortical region.

At the end of the IVM period $(24 \mathrm{~h})$, it is possible to note (Fig. 5) the large dark lipid droplets and numerous cortical granules on the oocyte periphery.

\section{Discussion}

The low number of COCs collected by OPU is probably the result of some peculiarities inherent to buffaloes, 


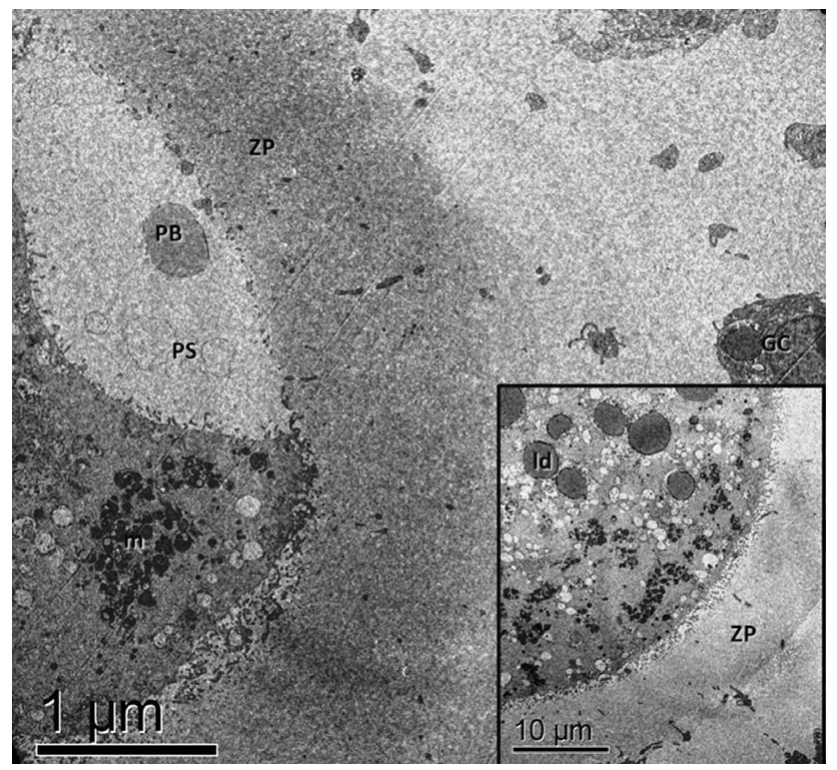

Figure 3 Twelve-hour matured oocyte (TEM), showing an extruded polar body $(\mathrm{PB})$ in a large perivitelline space (PS), peripherally located mitochondrial clusters (m). The granulosa cells (GC) are completely separated from zona pellucida (ZP). Note inset showing the change in the lipid droplets' (ld) aspect, probably denoting a chemical alteration in lipid molecules.

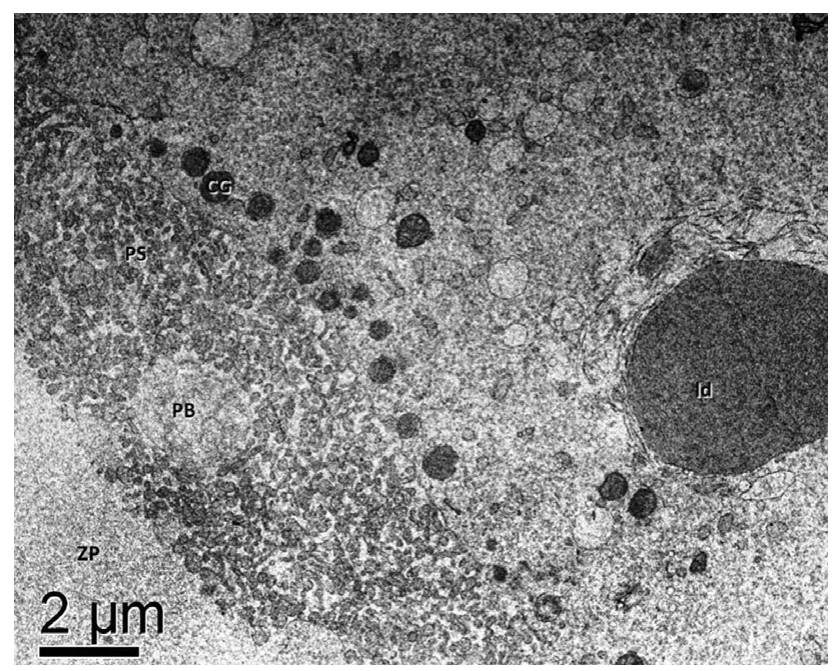

Figure 4 Eighteen-hour matured oocyte (TEM), showing an extruded polar body (PB) in a large perivitelline space (PS) filled with ooplasm villosites, apparently not embedded in zona pellucida (ZP). Note the peripherally located cortical granules $(\mathrm{CG})$ and the large lipid droplet (ld).

such as the reduced number of antral and preantral follicles, approximately ten times lower than in cattle (Drost, 2007; Mondadori et al., 2008). In addition, some hormonal protocols could increase the number of collected structures (Sá Filho et al., 2005). The number of COCs per ovary (approximately three structures),

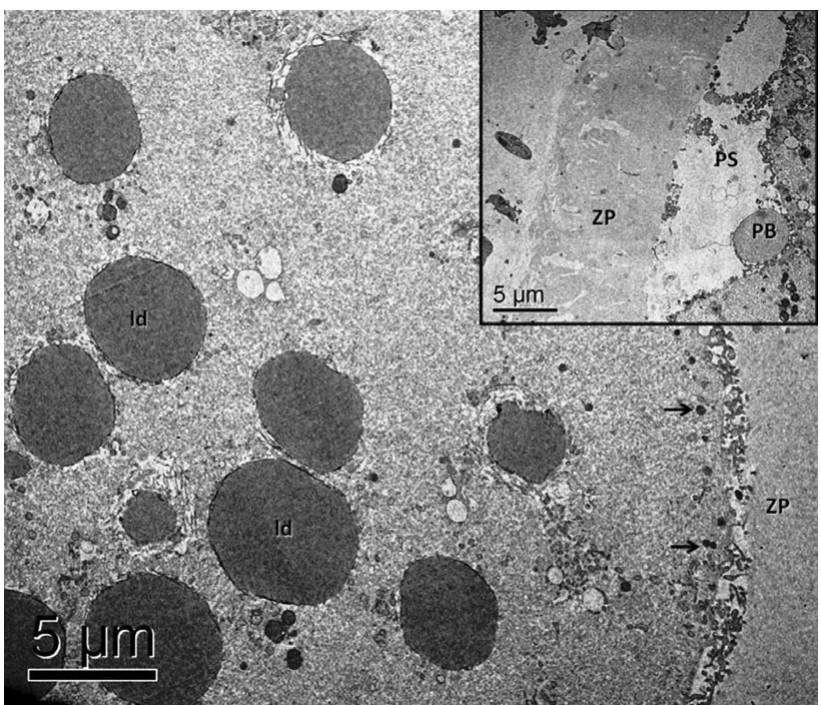

Figure 5 Twenty-four-hour matured oocyte (TEM), showing large lipid droplets (ld) and cortical granules (arrows). Note inset with extruded polar body (PB) in a large perivitelline space (PS) and an apparently loose zona pellucida (ZP).

was slightly higher than previously described in buffalo (Gasparrini, 2002; Drost, 2007; Manjunatha et al., 2008), the higher number of structures is probably caused by the longer interval between OPU sessions. The percentage of viable structures $(44 \%)$ was also higher than in one study (Baruselli et al., 2007) and lower than in another (Manjunatha et al., 2008). As previously described by Ferraz et al. (2007), in our study, a decrease in the number and in the quality of the oocytes was observed from the first to the last OPU.

\section{Ultrastructural changes during in vitro maturation}

Immature COCs showed typical structure previously described for buffalo (Boni et al., 1992; Mondadori et al., 2008), as well as for bovine (Hyttel et al., 1986; Kacinskis et al., 2005; Nagano et al., 2006), ovine (O'Brien et al., 2005) and camel (Kafi et al., 2005) oocytes. Confirming previous observations (Boni et al., 1992; Mondadori et al., 2008), the most important difference observed between the species is the larger number of lipid droplets in buffalo ooplasm. The same sort of GCoocyte junctions previously described for buffalo (Boni et al., 1992; Mondadori et al., 2008) and bovines (Fair \& Hyttel et al., 1997) was also observed in some immature oocytes. It is well known that these junctions play an important role during oogenesis (in buffalo after ZP formation -Mondadori et al., 2007) and IVM in different species (Zhang et al., 1995; Suzuki et al., 2000). The PS in most analysed immature oocytes was well developed, denoting that the structures were obtained from large antral follicles (Mondadori et al., 2008), whereas PS 
in immature bovine oocytes is absent or narrow (Hyttel et al., 1986). Evaluation of cattle and buffalo immature oocytes allows us to affirm that cortically located mitochondrial clusters and Golgi complex are ultrastructures that are characteristic of these structures in both species. It is also possible to infer that these functional complexes are involved in CG synthesis. This feature could also be used as a marker for oocyte competence because it only appears in oocytes originating from larger antral follicles (Mondadori et al., 2008).

From the start of IVM, as a result of the resumption of meiosis, nucleus morphology changes and PS grows, preparing to receive the polar body. After $6 \mathrm{~h}$ of IVM, the GC-oocyte junctions become loose; considering this, these cells probably do not play an important role in oocyte maturation during the rest of the IVM period. Instead, the separation is probably caused by GC hyaluronic acid production induced by gonadotrophins (Chen et al., 1990).

In most oocytes (three of five) studied, metaphase II stage was achieved much earlier (12 h of IVM) in contrast to earlier reports (Yadav et al. 1997; Santos et al., 2002; Nandi et al., 2002b; Gasparrini et al., 2008). From our point of view, as this experiment was not designed to determine oocyte maturation time point, this finding does not have a high biological value, because the number of observed oocytes (five structures) was low and the literature describes great biological variability in female buffalo reproductive patterns.

The most important change observed between 6 and $12 \mathrm{~h}$ of IVM is the change in lipid droplets, probably caused by chemical alteration in lipid molecules. It is well known that buffalo oocytes are more sensitive to oxidative damages because of their high lipid content (Boni et al., 1992; Mondadori et al., 2008). Boni et al. (1992) did not observe the lipid droplet changes, although our observation could explain the increasing proportion of tight morula and blastocyststage embryos when cysteamine is used on IVM medium (Gasparrini et al., 2000), and the confirmation that thiol compounds increase glutathione synthesis in buffalo oocytes (Gasparrini et al., 2006). Finally, it is important to observe that at the end of the IVM period, from 18 to $24 \mathrm{~h}$, the cortical granules are located on the ooplasm periphery, denoting preparation for polyspermy block (Cran \& Cheng, 1985).

It is concluded that: (1) immature oocytes in buffalo have a high lipid content; (2) the PS increases during IVM; (3) Golgi complexes and mitochondrial clusters migrate to the oocyte periphery during IVM, probably acting on CG synthesis; (4) $6 \mathrm{~h}$ of IVM are enough to lose contact between GC and ZP; and (5) the oocyte lipid droplets' aspect changes between 6 and $12 \mathrm{~h}$ of IVM.

\section{Acknowledgements}

The authors would like to thank Dr Rafael Afonso Dresh and Dr Emivaldo Siqueira Filho for helping with OPU sessions, and Nutricell Nutrientes Celulares for supplying media used in the experiment. This research was supported by CNPq, CAPES, FINEP, FINATEC and UPIS.

\section{References}

Baruselli, P.S. \& Carvalho, N.A.T. (2003). Controle do desenvolvimento folicular para o emprego de biotecnologias da reprodução em bubalinos (Bubalus bubalis). Rev. Bras. Repr. Anim. 27, 94-102.

Baruselli, P.S., Carvalho, N.A.T., Cavalcante, A.K.S., Nichi, M. \& Zicarelli, L. (2003). Use of rBST associated to a protocol for multiple ovulation and embryo transfer in buffalo (Bubalus bubalis). In: Proceedings of 2nd Congresso Nazionale Sull'Allevamento Del Buffalo, Roma. pp. 269-73.

Baruselli, P.S., Gimenes, L.U., Carvalho, N.A.T., Sá Filho, M.F., Ferraz, M.L. \& Barnabé, R.C. (2007). O estado atual da biotecnologia reprodutiva em bubalinos: perspectiva de aplicação comercial. Rev. Bras. Reprod. Anim. 31, 285-92.

Boni, R., Santella, L., Dale, B., Roviello, S., Di Palo, R. \& Barbieri, V. (1992). Maturazione in vitro di oociti buffalini: indagine ultrastrutturale. Acta Med. Vet. 38, 153-61.

Carvalho, N.A.T. (2001). Uso do agonista de GnRH deslorelina, associado ao $\mathrm{LH}$, para a superovulação de fêmeas bubalinas (Bubalus bubalis). Dissertação Mestrado em Reprodução Animal-Faculdade de Medicina Veterinária e Zootecnia da Universidade de São Paulo. São Paulo.

Chen, L., Wert, S.E., Hendrix, E.M., Russel, P.T., Cannon, M. \& Larsen, W.J. (1990). Hyaluronic acid synthesis are necessary for normal expansion of the cumulus mass. Mol. Reprod. Dev. 26, 236-47.

Cran, D.G. \& Cheng, W.T.K. (1985). Changes in cortical granules during porcine oocyte maturation. Gamete Res. 11, 311-9.

Drost, M. (2007). Advanced reproductive technology in the water buffalo. Theriogenology 68, 450-3.

Fair, T. \& Hyttel, P. (1997). Oocyte growth in cattle - ultrastructure, transcription and developmental competence. In: Motta, P. (ed.) Microscopy of Reproduction and Development: A Dynamic Approach. pp. 109-118.

Ferraz, M.L., Gimenes, L.U., Sá Filho, M.F., Watanabe, Y.F., Joaquim, D.C., Accorsi, M.F., Meirelles, F.V. \& Baruselli, P.S. (2007). Effect of OPU and bST treatment on embryo production in buffalo. In: Proceedings of the World Buffalo Congress, Caserta, Italy.

Fresicce, G.A. (2007). Reproduction in the water buffalo. Reprod. Dom. Anim. 42, 24-32.

Gasparrini, B. (2002). In vitro embryo production in buffalo species: state of the art. Theriogenology 7, 237-56.

Gasparrini, B., Neglia, G., Di Palo, R., Campanile, G. \& Zicarelli, L. (2000). Effect of cysteamine during in vitro maturation on buffalo embryo development. Theriogenology 54, 1537-42. 
Gasparrini, B., Boccia, L., Marchandise, J., Di Palo, R., George, F., Donnay, I. \& Zicarelli, L. (2006). Enrichment of in vitro maturation medium for buffalo (Bubalus bubalis) oocytes with thiol compounds: effects of cystine on glutathione synthesis and embryo development. Theriogenology 65, 27587.

Gasparrini, B., De Rosa, A., Attanasio, L., Boccia, L., Di Palo, R., Campanile, G. \& Zicarelli, L. (2008). Influence of the duration of in vitro maturation and gamete co-incubation on the efficiency on in vitro embryo development in Italian Mediterranean buffalo (Bubalus bubalis). Anim. Reprod. Sci. 105, 354-64.

Gupta, P.S.P., Ravindranatha, B.M., Nandi, S. \& Sarma, P.V. (2002). In vitro maturation of buffalo oocytes with an epidermal growth factor and fibroblast growth factor. Ind. J. Anim. Sci. 72, 23-6.

Hyttel, P. \& Madsen, I. (1987). Rapid method to prepare mammalian oocytes and embryos for transmission electron microscopy. Acta Anat. 129, 12-4.

Hyttel, P., Xu, K.P., Smith, S. \& Greve, T.U. (1986). Ultrastructure of in vitro oocyte maturation in cattle. Reprod. Fert. 78, 615-25.

Hyttel, P., Fair, T., Callesen, H. \& Greve, T. (1997). Oocyte growth, capacitation and final maturation in cattle. Theriogenology 47, 23-32.

Kacinskis, M.A., Lucci, C.M., Luque, M.C.A. \& Bao, S.N. (2005). Morphometric and ultrastructural characterization of Bos indicus preantral follicles. Anim. Reprod. Sci.47, 45-57.

Kafi, M., Mesbah, F., Nili, H. \& Khalili, A. (2005). Chronological and ultrastructural changes in camel (Camelus dromedarius) oocytes during in vitro maturation. Theriogenology 63, 2458-70.

Liang, X.W., Lu, Y.Q., Chen, M.T., Zhang, X.F., Lu, S.S., Zhang, M., Pang, C.Y., Huang, F.X. \& Lu, K.H. (2008). In vitro embryo production in buffalo (Bubalus bubalis) using sexed sperm and oocytes from ovum pick up. Theriogenology 69 , 822-6.

Manik, R.S., Singla, S.K., Palta, P. \& Chauhan, M.S. (2002). Ultrasonographic study of ovulation in buffalo following natural oestrus and after synchronization of oestrus by treatment with prostaglandin or norgestomed and estradiol valerate. Ind. J. Anim. Sci. 72, 145-7.

Manjunatha, B.M., Ravindra, J.P., Gupta, P.S.P., Devaraj, M. \& Nandi, S. (2008). Oocyte recovery by ovum pick up and embryo production in river buffaloes (Bubalus bubalis). Reprod. Dom. Anim. 43, 477-80.

Manjunatha, B.M., Ravindra, J.P., Gupta, P.S.P., Devaraj, M. \& Nandi, S. (2009). Effect of breeding season on in vivo oocyte recovery and embryo production in non-descriptive Indian river buffaloes (Bubalus bubalis). Anim. Reprod. Sci. 111, 37683.

Merchant, H. \& Chang, M.C. (1971). An electron microscopic study of mouse eggs matured in vivo and in vitro. Anat. Rec. 171, 21-38.

Misra, A.K., Kasiraj, R., Mutha Rao, M., Ragareddy, N.S., Jaiswal, R.S \& Pant, H.C. (1998). Rate of transport and development of preimplantation embryo in the superovulated buffalo (Bubalus bubalis). Theriogenology 50, 637-49.

Mondadori, R.G., Luque, M.C.A., Santin, T.R. \& Bao, S.N. (2007). Ultrastructural and morphometric characterization of buffalo (Bubalus bubalis) ovarian preantral follicles. Anim. Reprod. Sci. 97, 323-33.

Mondadori, R.G., Santin, T.R., Fidelis, A.A.G., Porfirio, E. \& Bao, S.N. (2008). Buffalo (Bubalus bubalis) preantral follicle population and ultrastructural characterization of antral follicle oocyte. Reprod. Dom. Anim. Epub ahead of print.

Moreira, F.C., Risco, M.F.A., Pires, J.D., Ambrose, M., Drost, M. \& Delorenzo, W.W. (2000). The effect of body condition on reproductive efficiency of lactating dairy cows receiving a timed insemination. Theriogenology 53, 1305-19,.

Nagano, M., Katagiri, S. \& Takahashi, Y. (2006). Relationship between bovine oocyte morphology and in vitro developmental potential. Zygote 14, 53-61.

Nandi, S., Raghu, H.M., Ravindranatha, B.M. \& Chauan, M.S. (2002a). Production of buffalo (Bubalus bubalis) embryos in vitro: premises and promises. Reprod. Dom. Anim. 37, 6574.

Nandi, S., Ravindranatha, B.M., Gupta, P.S.P. \& Sarma, P.V. (2002b). Timing of sequential changes in cumulus cells and first polar body extrusion during in vitro maturation of buffalo oocytes. Theriogenology 57, 1151-9.

O'Brien, J.K., Dwarte, D., Ryan, J.P., Maxwell, W.M. \& Evans, G. (2005). Developmental capacity, energy metabolism and ultrastructure of mature oocytes from prepubertal and adult sheep. Reprod. Fertil. Dev. 8, 1029-37.

Sá Filho, M.F., Carvalho, N.A.T., Gimenes, L.U., Torres Júnior, J.F., Garcia, J.M., Tonhati, H., Gasparrini, B. \& Baruselli, P.S. (2005). Efeito do bST na população folicular, na qualidade oocitária e na taxa de recuperação in vivo de oócitos em fêmeas bubalinas. In: Anais do Congresso Brasileiro de Reprodução Animal, vol. 16.

Santos, S.S.D., Dantas, J.K., Miranda, M.S. \& Ohashi, O.M. (2002). Cinética da maturação nuclear in vitro de oócitos bubalinos. Braz. J. Vet. Res. Anim. Sci. 39, 266-70.

Singh, J., Nanda, A.S. \& Adams, G.P. (2000). The reproductive pattern and efficiency of female buffaloes. Anim. Reprod. Sci. 60-61, 593-604.

Suzuki, H., Jeong, B.S. \& Yang, X. (2000). Dynamic changes of cumulus-oocyte cell communication during in vitro maturation of porcine oocytes. Biol. Reprod. 63, 723-9.

Yadav, B.R., Katiyar, P.K., Chauhan, M.S. \& Madan, M.L. (1997). Chromosome configuration during in vitro maturation of goat, sheep and buffalo oocytes. Theriogenology 47, 943-51.

Zamboni, L. \& Thomson, R.S. (1972). Fine morphology of human oocyte maturation in vitro. Biol. Reprod. 7, 42557.

Zhang, L., Jiang, S., Wozniak, P.J., Yang, X. \& Godke, R.A. (1995). Cumulus cell function during bovine oocyte maturation, fertilization, and embryo development in vitro. Mol. Reprod. Dev. 40, 338-44. 